\title{
Cytotoxicity and apoptotic effects of nickel oxide nanoparticles in cultured HeLa cells
}

\author{
Kezban Ada ${ }^{1}$, Mustafa Turk², Serpil Oguztuzun², Murat Kilic ${ }^{2}$, Mehmet Demirel ${ }^{1}$, \\ Nisa Tandogan², Ertan Ersayar ${ }^{2}$, Ozturk Latif ${ }^{3}$ \\ ${ }^{1}$ Kirikkale University Faculty of Art and Sciences, Department of Chemistry, Kirikkale, Turkey \\ ${ }^{2}$ Kirikkale University Faculty of Art and Sciences, Department of Biology, Kirikkale, Turkey \\ ${ }^{3}$ Kirikkale University Faculty of Economics and Administrative Sciences, Department of Economics, \\ Kirikkale, Turkey
}

\begin{abstract}
The aim of this study was to observe the cytotoxicity and apoptotic effects of nickel oxide nanoparticles on human cervix epithelioid carcinoma cell line (HeLa). Nickel oxide precursors were synthesized by an nickel sulphate-excess urea reaction in boiling aqueous solution. The synthesized $\mathrm{NiO}$ nanoparticles $(<200 \mathrm{~nm})$ were investigated by X-ray diffraction analysis and transmission electron microscopy techniques. For cytotoxicity experiments, HeLa cells were incubated in $50-500 \mu \mathrm{g} / \mathrm{mL} \mathrm{NiO}$ for 2, 6, 12 and 16 hours. The viable cells were counted with a haemacytometer using light microscopy. The cytotoxicity was observed low in $50-200 \mu \mathrm{g} / \mathrm{mL}$ concentration for $16 \mathrm{~h}$, but high in $400-500 \mu \mathrm{g} / \mathrm{mL}$ concentration for 2-6 h. HeLa cells' cytoplasm membrane was lysed and detached from the well surface in $400 \mu \mathrm{g} / \mathrm{mL}$ concentration $\mathrm{NiO}$ nanoparticles. Double staining and M30 immunostaining were performed to quantify the number of apoptotic cells in culture on the basis of apoptotic cell nuclei scores. The apoptotic effect was observed $20 \%$ for $16 \mathrm{~h}$ incubation.
\end{abstract}

Key words: $\mathrm{NiO}$ nanoparticles, cancer, toxicity, apoptosis

\section{Introduction}

Man-made nanoparticles and materials are being rapidly produced in large quantities throughout the world [1]. Many studies conducted in the past ten years suggest that nanomaterials have different toxicity profiles compared with larger particles because of their small size and high reactivity. As more and more nanomaterials are introduced into our daily life, there is a serious lack of information concerning their human health and environmental implications [2]. The integration of nanotechnology and biology provides the opportunity for the development of new materials in the nanometer size range with many potential applications in biological sciences and clinical medicine [3-6].

Nanomedicine, which is the application of nanotechnology to medical problems, can offer new

Correspondence: K. Ada, Kirikkale University Faculty of Art and Sciences, Department of Chemistry, Kirikkale, Turkey; tel.: (+090318) 3574242, fax.: (+090318) 3572461,

e-mail:kezbanada@mynet.com approaches. With regards to cancer treatment, most current anticancer regimes do not effectively differentiate between cancerous and normal cells. This indiscriminate action frequently leads to systemic toxicity and debilitating adverse effects in normal body tissues including bone marrow suppression, neurotoxicity, and cardiomyopathy. Nanotechnology and nanomedicine can offer a more targeted approach which promises significant improvements in the treatment of cancer $[7,8]$.

Regarded as an important component in the development of nanotechnology, nanoparticles (NPs) have been extensively explored for possible medical applications [9-12]. As for metal oxide nanoparticles, the small size and large specific surface area endow them with high chemical reactivity and intrinsic toxicity. To date, most nanotoxicity research has been focused on individual nano-sized metal oxides. The potential toxicity of nanoparticles, including nickel oxide $(\mathrm{NiO})$, titanium dioxide $\left(\mathrm{TiO}_{2}\right)$, carbon nanotubes, and fullerenes, has drawn significant attention [13-16]. For example, $\mathrm{NiO}$ particles have been shown to trigger 
reactive oxygen species (ROS) that cause DNA damage in lungs of rats [13]. Dunnick and coworkers showed that chronic exposure to nickel can cause lung neoplasms in rats. It has been proposed that nickel migrate to the nuclear membrane, where they release nickel ions that effect DNA damage [15]. Interestingly, because of its toxicity, nano-sized $\mathrm{NiO}$ could be used to fight cancer. The aim of this study was to observe the cytotoxicity and apoptotic effects of nickel oxide $(\mathrm{NiO}) \mathrm{NPs}$ synthesized in our laboratory on human cervix epithelioid carcinoma cell line (HeLa).

\section{Materials and methods}

Preparation of NiO nanoparticles. The homogeneous precipitation method in aqueous solution and some physicochemical properties of such oxide powders as $\mathrm{Al}_{2} \mathrm{O}_{3}$ and $\mathrm{ZnO}$ were investigated in our previous work $[17,18]$. The analytical grade chemicals used in this study, namely, $\mathrm{NiSO}_{4} \cdot 6 \mathrm{H}_{2} \mathrm{O}, \mathrm{CO}\left(\mathrm{NH}_{2}\right)_{2}, 65 \% \mathrm{HNO}_{3}$ $(1.40 \mathrm{~g} / \mathrm{mL})$ and $25 \% \mathrm{NH} 3(0.91 \mathrm{~g} / \mathrm{mL})$ were supplied by Merck Company, Germany. Nickel oxide precursors were precipitated by the same method from a boiling aqueous solution containing 0.30 $\mathrm{M} \mathrm{Ni}^{+2}$ and excess urea. A $0.8 \mathrm{M} \mathrm{Ni}^{2+}$ stock aqueous solution was prepared and this solution having $0.3 \mathrm{M} \mathrm{Ni}^{2+}$ and the ratio of [urea] $/\left[\mathrm{Ni}^{2+}\right]=10$ were prepared by using the stock solution and excess urea. The $\mathrm{pH}$ value of this solution necessary for the precipitation of $\mathrm{Ni}(\mathrm{OH})_{2}$ was adjusted to 6.91 by adding $0.1 \mathrm{M} \mathrm{NH} 3$ solution drop by drop. The Bunsenite-NiO powder having the surface area $8.0 \mathrm{~m}^{2} \mathrm{~g}^{-1}(\mathrm{BET})$ was obtained by the calcination of the precursors at $500^{\circ} \mathrm{C}$ for 2 hours. JEOL JEM-transmission electron microscopy (TEM ) images were taken to determine the morphology and dimension of the nanoparticles. X-ray diffraction (XRD) pattern of nickel oxide were recorded by a Rikagu D-max 2200 powder diffractometre with a Ni filter and $\mathrm{CuK}_{\alpha} \mathrm{X}$-rays having $0.15418 \mathrm{~nm}$ wavelength.

Cell source and culture. Human cervix epithelioid carcinoma cell line (HeLa) was obtained from the tissue culture collection of the SAP Institute of Culture Collection, Ankara, Turkey. Cell culture flasks and other plastic material were purchased from Corning, NY, USA. The growth medium, which is Dulbecco Modified Medium (DMEM-F12) without L-glutamine, supplemented fetal calf serum (FCS), and Trypsin-EDTA were purchased from Biological Industries Ltd., Kibbutz Beit Haemek, Israel.

Cell culture. HeLa cells were cultured in DMEM-F12 medium supplemented with $10 \%$ FCS and $1 \%$ antibiotic (10.000 unit of penicilin and streptomycin $10 \mathrm{mg} / \mathrm{ml}$ in $100 \mathrm{ml}$ of sterile distilled water) in a humidified incubator at $37^{\circ} \mathrm{C}$ and $5 \% \mathrm{CO}_{2}$ atmosfer. The cells were subcultered twice a week, using dissociation medium ( trypsin-EDTA, pH 7.4) as buffer system [19].

Cytotoxicity. For cytotoxicity experiments, HeLa cells $\left(25 \times 10^{3}\right.$ cells per well) were placed in DMEM-F12 by using 24-well plates. $1 \mu \mathrm{g} / \mathrm{mL} \mathrm{NiO}$ nanoparticle solution in $0.15 \mathrm{M} \mathrm{NaCl}$ was prepared and this solution was sonicated and filtered by $0.2 \mu \mathrm{m}$ filter. Different amounts of $\mathrm{NiO}(50-500 \mu \mathrm{g} \mathrm{NiO}$ per $\mathrm{mL})$ were put into wells containing cells. The plates were kept in the $\mathrm{CO} 2$ incubator $\left(37^{\circ} \mathrm{C}\right.$ in $\left.5 \% \mathrm{CO}_{2}\right)$ for $2-16 \mathrm{~h}$. Following this incubation, HeLa cells were harvested with trypsin-EDTA. They were dyed with trypan blue (19). The viable cells were counted with a haemacytometer (C.A. Hausse\& Sons, Phluila, USA), using light microscopy (Leica, Germany).
Double staining. Double staining were performed to quantify the number of apoptotic cells in culture on basis of scoring of apoptotic cell nuclei. HeLa cells $\left(25 \times 10^{3}\right.$ cells per well $)$ were placed in DMEM -F12 by using 24-well plates. After treating with different amounts of $\mathrm{NiO} \mathrm{NPs}(50-500 \mu \mathrm{g} \mathrm{NiO}$ per $\mathrm{mL})$ for 2-16 hours period, both attached and detached cells were collected. They were washed with PBS and stained with Hoechst dye $33342(2 \mu \mathrm{g} / \mathrm{mL})$, propodium iodide (PI) $(1 \mu \mathrm{g} / \mathrm{mL})$ and DNAse free-RNAse $(100 \mu \mathrm{g} / \mathrm{mL})$ for 15 minutes at room temperature. Subsequently, $10-50 \mu 1$ of cell suspension was smeared on slide and coverslip for examination by fluorescence microscopy (Fluorescence Inverted Microscope, Olympus IX70, Japan) [20,21]. The nuclei of normal cells were stained blue but apoptotic cells were stained bright blue by the Hoechst dye. Necrotic cells were staining red by PI. Necrotic cells lacking plasma membrane integrity and PI dye crossed cell membrane, but PI dye did not cross non-necrotic cell membrane. The number of apoptotic and necrotic cells in 10 randomly chosen microscopic fields were counted and the result was expressed as a ratio of the number of apoptotic or necrotic cells to the number of normal cells. The apoptotic cells were identified by their nuclear morphology as a nuclear fragmentation or chromatin condensation. This experiment was repeated five times.

M30 immunostaining. The percentage of apoptotic cells was determined by M30 CytoDEATH antibody (Roche). This is a monoclonal mouse immunoglobulin (Ig) G2b antibody (clone M30; Roche, Mannheim, Germany) that binds to a caspase-cleaved, formalin-resistant epitope of the cytokeratin 18 cytoskeletal protein which was found only in epithelial cell. M30 immunostaining was only for HeLa cells. The immunoreactivity of the M30 antibody was confined to the cytoplasm of apoptotic cells. HeLa cells, treated with $\mathrm{NiO}(50-500 \mu \mathrm{g} \mathrm{NiO}$ per $\mathrm{mL}$ ) for a 2-16 hour period, were cytocentrifuged, treated with $0.3 \%$ hydrogen peroxide in methanol for $10 \mathrm{~min}$ to block the endogenous peroxidase activity, washed in PBS, and then incubated with M30 antibody (1:50 dilution) at room temperature for $1 \mathrm{~h}$. In negative controls, preimmune mouse serum, instead of primary antibody, was used. Immunoreactions were revealed by the avidin-biotin complex technique using diaminobenzidine (DAB) as substrate. We counted the number of M30-positive cytoplasmic staining cells in all fields found at $\times 400$ final magnification. For each slide, three randomly selected microscopic fields were observed, and at least 1000 cells/field were evaluated. This experiment was repeated 3 times.

Statistical analysis. Two-way analysis of variance (ANOVA) tests (SPSS 1.9) can be used to test for differences in the exposure time and doses of NiO NPs on HeLa cells for cytotoxicity, apoptosis and necrosis assays.

\section{Results}

\section{Electron microscopy}

The TEM photograph for the NiO powders is presented in Fig. 1. It is clearly observed from this photograph that the shape of the powder particles is spherical, and some of these unequally sized spherical particles are agglomerated. From the images, the average size of the nanoparticles is around $20 \mathrm{~nm}$.

\section{XRD ( X Ray Differaction) analysis}

The XRD patterns of the $\mathrm{NiO}$ powders that were examined are presented in Fig. 2. The Miller indices of 
Table 1. Apoptosis induction by the Hoechst and M30 immunostaining assays, necrosis induction by the propodium iodide (PI) staining detected. The apoptosis and necrosis assays by light microscopy following 2, 6 and 16-h exposure of HeLa cells to NiO NPs. The Hoechst/PI double staining and the M30 staining were repeated five and three times, respectively.

\begin{tabular}{|c|c|c|c|c|c|c|c|c|c|c|c|c|}
\hline \multirow{3}{*}{$\begin{array}{c}\text { Exposure } \\
\text { time } \\
\text { (hours) }\end{array}$} & \multicolumn{4}{|c|}{ Necrosis \% (PI) Stainig } & \multicolumn{4}{|c|}{ Apoptosis \% (Hoechst) Staining } & \multicolumn{4}{|c|}{ Apoptosis \% (M30) Staining } \\
\hline & \multicolumn{4}{|c|}{$\operatorname{dosc}(\mu \mathrm{g} / \mathrm{ml})$} & \multicolumn{4}{|c|}{$\operatorname{dose}(\mu \mathrm{g} / \mathrm{ml})$} & \multicolumn{4}{|c|}{$\operatorname{dose}(\mu \mathrm{g} / \mathrm{ml})$} \\
\hline & 0 & 100 & 250 & 500 & 0 & 100 & 250 & 500 & 0 & 100 & 250 & 500 \\
\hline 2 & $2.09 \pm 0.05$ & $4.93 \pm 0.12$ & $14.85 \pm 0.25$ & $74.56 \pm 0.32$ & $0.06 \pm 0.06$ & $0.06 \pm 0.1$ & $2.45 \pm 0.39$ & $3.48 \pm 0.22$ & $0.07 \pm 0.03$ & $0.08 \pm 0.02$ & $2.38 \pm 0.12$ & $3.4 \pm 0.18$ \\
\hline 6 & $3.76 \pm 0.42$ & $10.48 \pm 0.2$ & $18.47 \pm 0.59$ & $84.45 \pm 0.96$ & $0.95 \pm 0.07$ & $1.38 \pm 0.17$ & $2.49 \pm 0.19$ & $4.36 \pm 0.13$ & $1.45 \pm 0.2$ & $1.27 \pm 0.07$ & $2.35 \pm 0.24$ & $4.45 \pm 0.2$ \\
\hline 16 & $8.05 \pm 0.15$ & $10.56 \pm 0.3$ & $23.35 \pm 0.46$ & $70.48 \pm 0.82$ & $1.96 \pm 0.09$ & $2.08 \pm 0.11$ & $10.29 \pm 0.26$ & $20.46 \pm 0.44$ & $2.38 \pm 0.2$ & $2.42 \pm 0.2$ & $10.43 \pm 0.07$ & $20.15 \pm 0.81$ \\
\hline
\end{tabular}

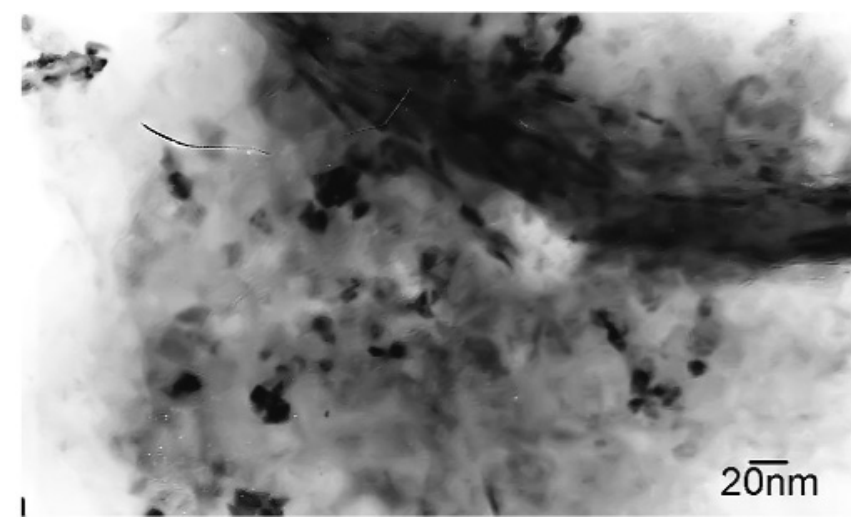

Fig. 1. The Transmission Electron Microscope (TEM) photograph for $\mathrm{NiO}$ powder. (original magnification $\times 108000$ ).

the reflective crystal planes between them are indicated on the XRD patterns. Nickel oxide crystal has several XRD reflections. Its characteristic XRD reflections at $37.3,43.2,62.8,75.2$ and $79.4^{\circ}$ correspond to $111,200,220,311$ and 222 planes, respectively. The diffraction angle and intensity of the characteristic sharp peaks in the pattern can be exactly indexed (JCPDS Card No.04-0835) to a cubic structure of NiO [22-25].

\section{Cytotoxicity}

In this study, we investigated the cytotoxicity of $\mathrm{NiO}$ NPs. The percentages of viable cells with different incubation times and concentrations of NiO NPs are shown in Fig. 3. Note that wells not containing NiO NPs were also studied as positive control. NiO NPs did not cause any observable toxicity in the range of 50$300 \mu \mathrm{g} / \mathrm{mL}$ concentration that we used in this study. The increase in the amount of NiO NPs (added in each well) caused more toxicity (more dead cells), as expected. The toxicity of NiO NPs to the HeLa cells increased with the increase of particle quantity from 350 to $500 \mu \mathrm{g}$ per well. According to the Fig. 3, however, NiO NPs did not show high toxicity at all for 2-16h incubation at $37^{\circ} \mathrm{C}$ even though the amount of particles was increased from 50 to $300 \mu \mathrm{g} / \mathrm{well}$. But

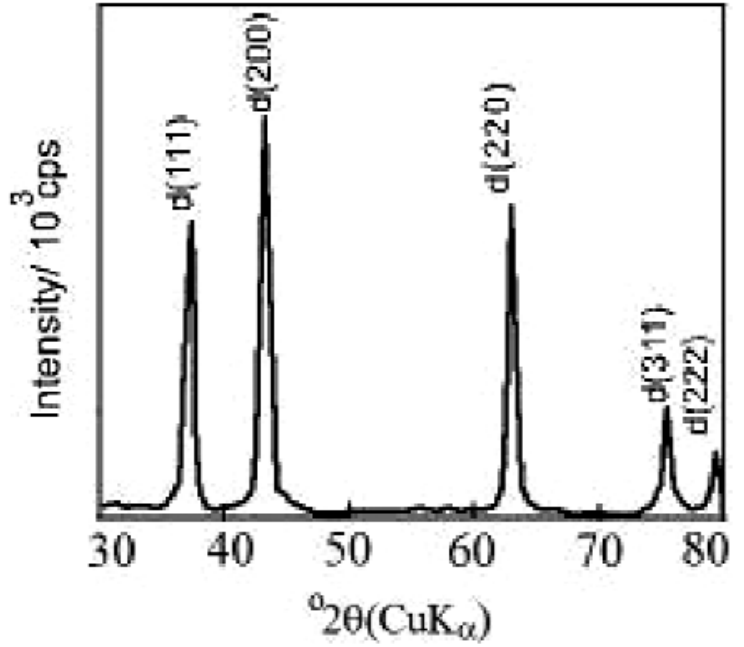

Fig. 2. The X-ray diffraction patterns for $\mathrm{NiO}$ powder.

when HeLa cells were incubated for $6 \mathrm{~h}$, cytotoxicity of NiO NPs (350 $\mu \mathrm{g} /$ well and above) were started to be observed. As the amount of NiO NPs and their incubation time increased, toxicity of culture cells was increased. NiO NPs have high toxicity at $500 \mu \mathrm{g} /$ well. Results showed that NiO NPs was highly toxic to cells at $500 \mu \mathrm{g} / \mathrm{well}$. The values of cytotoxicity induced by $\mathrm{NiO}$ NPs were given in Fig. 3. Treatment with $\mathrm{NiO}$ NPs produced a dose-dependent decrease in cell viability. A significant reduction was found at $350 \mu \mathrm{g} / \mathrm{mL}$ $\mathrm{NiO}$ NPs for 2, 6, 12 and $16 \mathrm{~h}$, with a decrease to 71, 53,42 and $41 \%$, respectively (Fig. 3). Treatment with $\mathrm{NiO}$ NPs also induced cytotoxicity in a time-dependent manner, as the percentage of viability decreased significantly following longer exposure $(\geq 16 \mathrm{~h})$, at a dose of $500 \mu \mathrm{g} / \mathrm{mL}$ (Fig. 3). The inhibition of cell population growth by NiO NPs was both dose-dependent and time-dependent $(\mathrm{p}=0.00<0.05)$ (Fig. 3).

\section{Apoptosis and necrosis}

In order to quantitatively analyze apoptotic and necrosis cells under NiO NPs treatment, M30 immunostaining (Figs 4a and $4 \mathrm{~b}$ ) and double staining (Figs 5a and $5 b)$ assays were employed. Table 1 summarizes the 


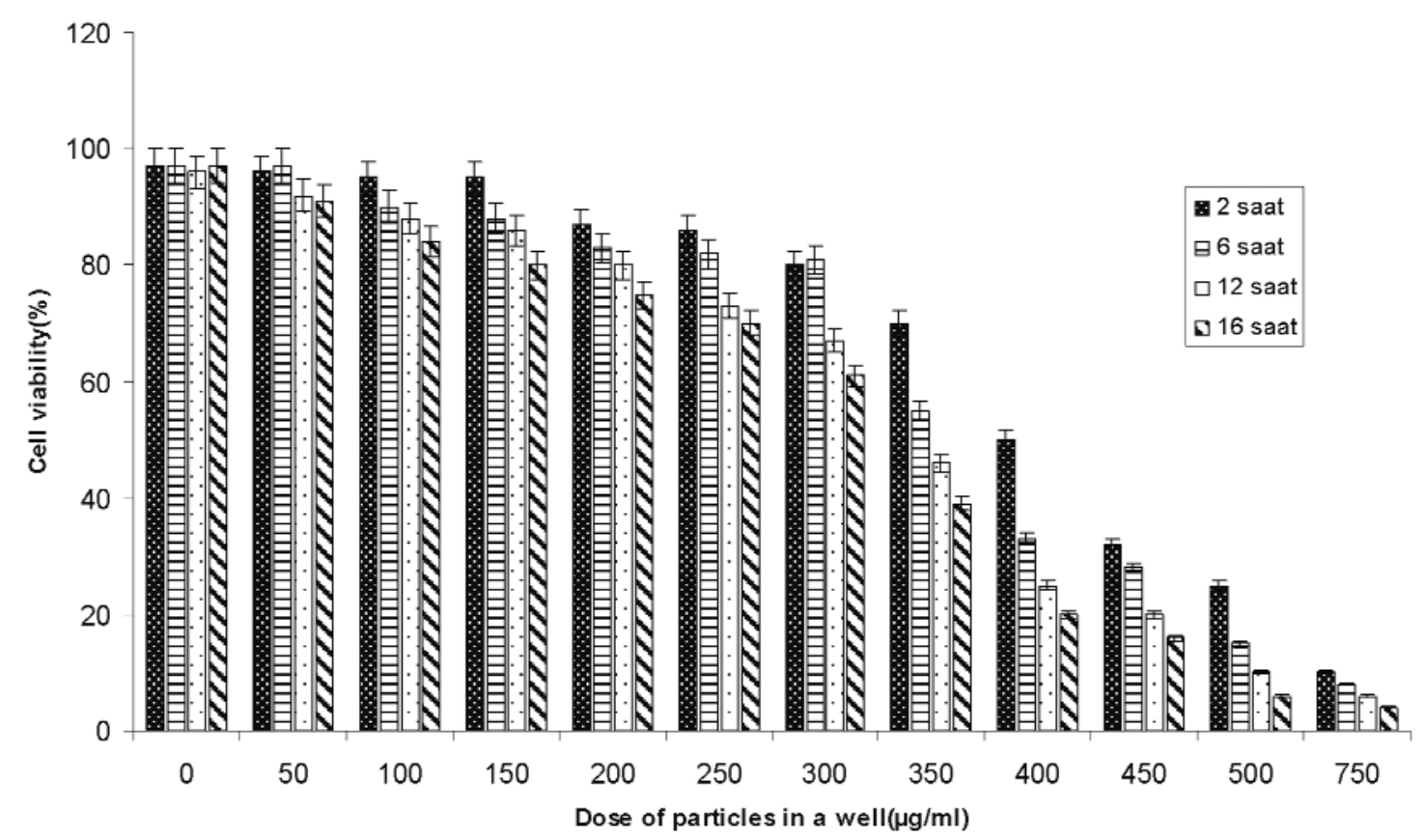

Fig. 3. Cell viability monitored by the cytotoxicity assay following $2,6,12,16-\mathrm{h}$ exposure of HeLa cells to NiO NPs. Data are shown as $\%$ of viable cells compared to dose of particles and are presented as mean $\pm \mathrm{SEM}$ of twelve separate experiments.

results of apoptosis and necrosis induced by NiO NPs detected by the double staining and M30 immunostaining assay. Statistically, apoptosis and necrosis were both dose-dependent and time-dependent $(\mathrm{p}=0.00<0.05)$. As Fig. 4a shows, in the control group, no apoptosis happened after $16 \mathrm{~h}$ incubation. However, when the cells were treated with NiO NPs, the numbers of apoptotic and necrosis cells increased markedly (Fig. 4b). Furthermore, as the exposure time was prolonged from 2 to $16 \mathrm{~h}$, the total number of apoptotic cells increased from $0 \%$ to $20 \%$. The apoptosis or necrosis pathway of HeLa cells caused by $\mathrm{NiO}$ NPs is not yet clear.

\section{Discussion}

Cytotoxicity studies of metal based nanomaterials have been mainly focused on the metal nanoparticles. Griffitt and coworkers [26] reported that the exposure to copper nanoparticles caused the gill injury and acute lethality in zebrafish Danio rerio. Wang and coworkers [27] determined the acute toxicity of nano- and microscale zinc powder in vivo, detected the acute toxicity of copper nanoparticles in vivo, and offered the explanation that the ultrahigh reactivity provoked the nanotoxicity of nano-copper particles [28,29]. To date, limited research has been conducted regarding the nano-sized metal oxide except for $\mathrm{TiO}_{2}$. Wang and coworkers [30] also determined the acute toxicity of $\mathrm{TiO}_{2}$ particles of different sizes in mice and found that the $\mathrm{TiO}_{2}$ was retained in the liver, spleen, kidneys, and lung tissues. According to Wang and coworkers [30], the ultrafine $\mathrm{TiO}_{2}$ can cause genotoxicity and cytotoxicity in cultured human lymphoblastoid cells.

Because nanoparticles can interact with cell membranes and intracellular organelles in ways that are not totally understood, there are increasing concerns about the adverse health effects of NiO NPs and other nanoparticles. The first part of this study was to analyze the cell toxicity effects of unmodified NiO NPs.

The previous data [31] have indicated that nickel (Ni) ion binds to DNA and subsequently reacts with $\mathrm{H}_{2} \mathrm{O}_{2}$ to cause strong DNA damage. The other mechanism is indirect oxidative DNA damage due to inflammation. Important sources of endogenous oxygen radicals are phagocytic cells such as neutrophils and macrophages [32]. It has been proposed that reactive oxygen species (ROS) including nitrogen oxide generated in inflamed tissues can cause injury to target cells and also damage DNA, which contributes to carcinogenic processes [33-35]. Based on the above overall model, two mechanisms for nickel-induced oxidative DNA damage have been proposed as follows: all the nickel compounds tested induced indirect damage through inflammation, and $\mathrm{Ni}_{3} \mathrm{~S}_{2}$ also showed direct oxidative DNA damage through $\mathrm{H}_{2} \mathrm{O}_{2}$ formation. This double action may explain the relatively high carcinogenic risk associated with $\mathrm{Ni}_{3} \mathrm{~S}_{2}$.

The results of the present study demonstrate that NiO NPs induce significant cytotoxicity in cultured $\mathrm{HeLa}$ cells. The results from the cytotoxicity assay (Fig. 4) indicated that NiO NPs killed the cells in both 

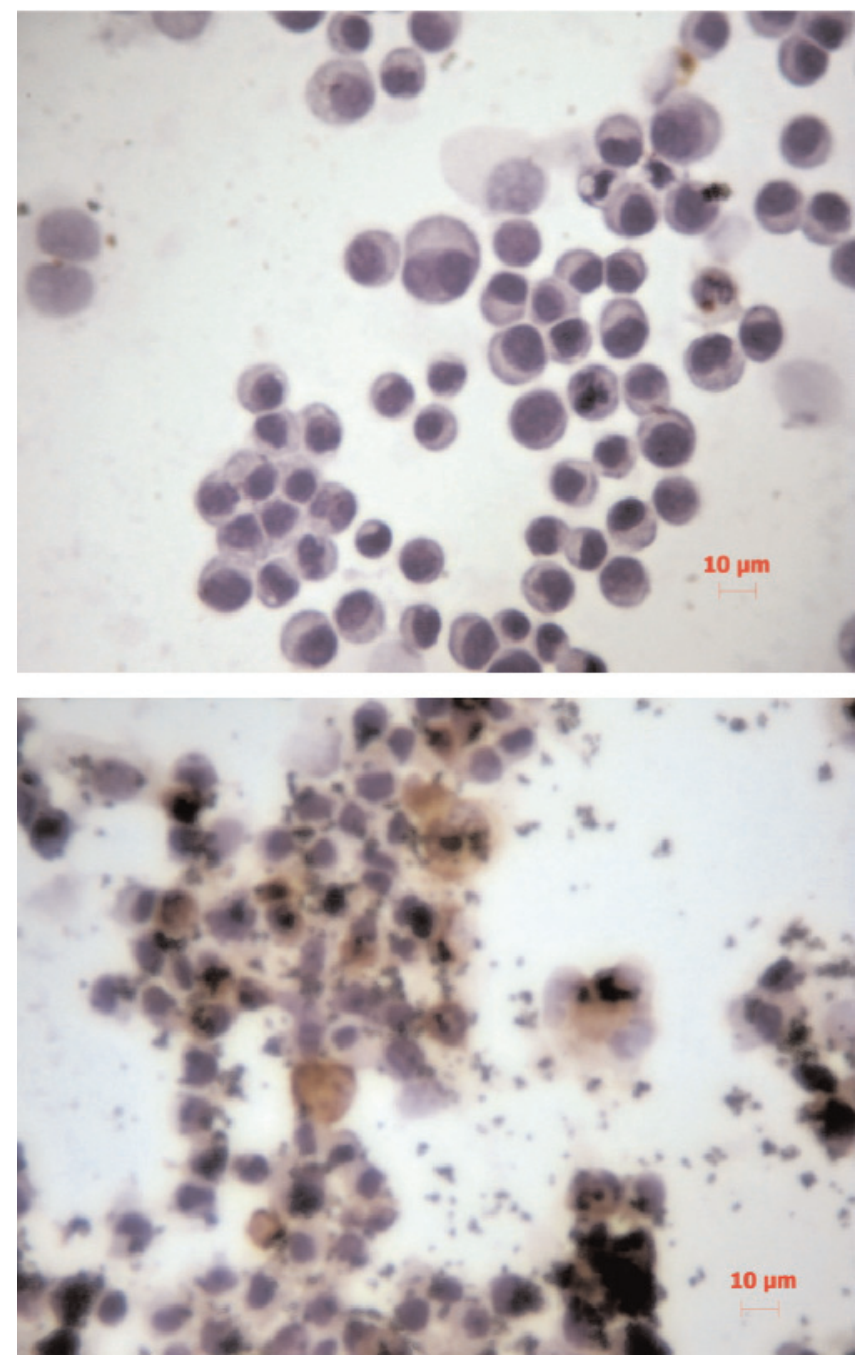

Fig. 4. (a) HeLa cells control (b) $\mathrm{NiO} \mathrm{NPs}(500 \mu \mathrm{g} / \mathrm{mL})$ applicated HeLa cells, the cytoplasms of apoptotic cells were stained brown, (stained with M30 CytoDEATH antibody) original magnification $\times 400$ (black dots show that paticles aggreations).

a dose-dependent and a time-dependent manner. In agreement with our results, apoptosis induced by mutagenic carcinogens is a unique type of programmed cell death. It has been reported that the reaction of particles with cell membranes results in the generation of ROS, and the generated oxidative stress may cause a breakdown of membrane lipids, leading to an imbalance of intracellular calcium homeostasis, alterations in metabolic pathways, and finally results in apoptosis [36,37]. In our study, inductions of apoptosis and necrosis were observed following exposure to NiO NPs as measured by the double staining and M30 immunostaining assay (Table 1).

The two methods that uses monoclonal antibody M30 and Hoechst staining should be used together for the sensitivity of apoptotic index. They were exclusively expressed in apoptotic epithelial cells $[20,21,38,39]$. M30 and Hoechst staining has been shown to be
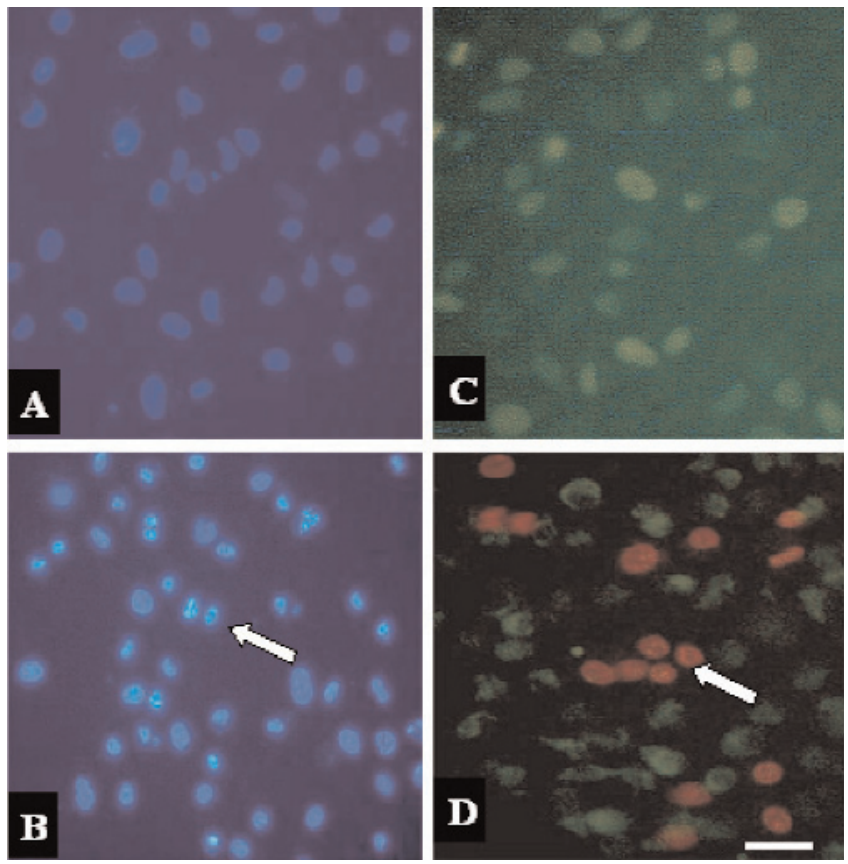

Fig. 5. (a) Fluorescent microscope image of nucleus of NiO NPs $(500 \mu \mathrm{g} / \mathrm{mL})$ applicated HeLa cells, cells stained with Hoescht (the excitation wavelenght of fluorescence was 346 , the emission wavelenght of fluorescence was 460) bright blue spots (arrow) were demostrated nucleus of apoptotic cells. (b) The images of Hoechst-stained control (untreated) cells (c) The images of PIstained control (untreated) cells. (d) Fluorescent microscope image of nucleus of NiO NPs $(500 \mu \mathrm{g} / \mathrm{mL})$ applicated HeLa cells, cells stained with PI (the excitation wavelenght of fluorescence was 536, the emission wavelenght of fluorescence was 617), red spots were demostrated nucleus of necrotic cells, original magnification $\times 400$ (scale bar is $20 \mu \mathrm{m}$ ).

positive in epithelial cells that have apoptotic characteristics such as chromatin condensation, nuclear fragmentation and detachment of cytoplasm [40, 21].

However, the precise mechanism of apoptosis formation by NiO NPs is unclear. Additional work needs to be undertaken to understand the mechanisms of damage.

\section{References}

[ 1] Guzman K A D, Taylor McNeil S E. Nanotechnology for the biologist. J Leukoc. Biol. 2005;78:585-94.

[ 2] Gregory L. Baker,1 Amit Gupta, Mark L. Clark, Blandina R. Valenzuela, Lauren M. Staska, Sam J. Harbo, Judy T. Pierce, and Jeffery A. Dill Inhalation Toxicity and Lung Toxicokinetics of C60 Fullerene Nanoparticles and Microparticles. Toxicol Sci. 2008;101(1):122-131.

[3] Lanone S and Boczkowski J. Biomedical applications and potential health risks of nanomaterials: molecular mechanisms. Curr Mol Med. 2006;6:651-63.

[4] Groneberg D A, Giersig M, Welte T and Pison U. Nanoparticle-based diagnosis and therapy. Curr Drug Targets. 2006;7: 643-8.

[ 5] Hu X, Cook S, Wang P, Hwang H. In vitro evaluation of cytotoxicity of engineered metal oxide nanoparticles. Sci Tot Environm. 2009;407:3070-3072 
[6] Nie S, Xing Y, Kim GJ and Simons JW. Nanotechnology applications in cancer. Ann Rev Biomed Eng. 2007;9:257-88.

[7] Bosanquet AG and Bell PB. Ex vivo therapeutic index by drug sensitivity assay using fresh human normal and tumor cells. J Exp Ther Oncol. 2004;4:145-54.

[ 8] Cory H, Janet L, Alex P, Isaac C, Andrew C, Kevin F, Denise W. Preferential killing of cancer cells and activated human T cells using ZnO nanoparticles. Nanotechnology. 2008;19: 295103.

[ 9] Bhattacharyya R, Patra CR, Verna R, Kumar S, Greipp PR, Mukherjee P. Gold nanoparticles inhibit the proliferation of multiple myeloma cells. Advanced Materials. 2007;19:711-6.

[10] Yezhelyev MV, Gao X, Xing Y, Al-Haj A, Nie S, O'Regan R. Emerging use of nanoparticles in diagnosis and treatment of breast cancer. Lancet Oncol. 2006;7:657-67.

[11] Vamanu C, Mihaela R. Cimpan, Paul J. Hol, Steinar Sornes, Stein A. Lie, Nils R. Gjerdet. Induction of cell death by TiO2 nanoparticles: Studies on a human monoblastoid cell line. Toxicology in Vitro. 2008;22:1689-1696.

[12] Jingxia Z, Lanju X, Tao Z, Guogang R, Zhuo Y. Influences of nanoparticle zinc oxide on acutely isolated rat hippocampal CA3 pyramidal neurons. Neurotoxicology. 2009;30:220-230.

[13] Kawanishi S, Oikawa S, Inoue S, and Nishino K. Distinct mechanisms of oxidative DNA damage induced by carcinogenic nickel subsulfide and nickel oxides. Environmental Health Perspectives. 2002;110(suppl 5):789-791.

[14] Takahashi S, Yamada M, Kondo T, Sato H, Furuya K and Tanaka I. Cytotoxicity of Nickel oxide particles in rat alveolar macrophages cultured in vitro. J Toxicol Sci.1992;17:243-251.

[15] Dunnick JK, Elwell MR, Radovsky AE, Benson JM, Hahn FF, Nikula KJ, Barr EB, and Hobbs CH. Comparative carcinogenic effects of Nickel Subsulfide, nickel oxide, or nickel sulfate hexahydrate chronic exposures in the lung. Cancer Research. 1995;55:5251-5256.

[16] Thevenot P, Cho J, Wavhal D, Timmons RB, Tang L. Surface chemistry influences cancer killing effect of $\mathrm{TiO}_{2}$ nanoparticles. Nanomedicine: Nanotechnology, Biology, and Medicine. 2008;4:226-236..

[17] Ada K, Sarikaya Y, Alemdaroglu T, Onal M. Thermal behaviour of alumina precursor obtained by the aluminium sulphate-urea reaction in boiling aqueous solution. Ceramics International. 2003;29:513-518.

[18] Ada K, Gökgöz M, Önal M, Sarikaya Y. Preparation and characterization of a $\mathrm{ZnO}$ powder with the hexagonal plate particles. Powder Tech. 2008;181:85-29.

[19] Turk M, Dincer S, Yulug IG, Piskin E. In vitro transfection of HeLa cells with temperature sensitive polycationic copolymers. J Control Release. 2004;96(2):325-40.

[20] Choi S, Oh J and Choy J. Toxicological effects of inorganic nanoparticles on human lung cancer A549 cells. J Inorg Biochem. 2009;103(3):463-71.

[21] Ulukaya E, Kurt A, Wood E J. 4-(N-Hydroxyphenyl)retinamide Can Selectively Induce Apoptosis in Human Epidermoid Carcinoma Cells But Not in Normal Dermal Fibroblasts. Cancer Investigation. 2001;19(2):145-154.

[22] Tao D, Wei F. New procedure towards size-homogeneous and well- dispersed nickel oxide nanoparticles of $30 \mathrm{~nm}$. Materials Letters. 2004;58:3226-3228.

[23] Wu Y, He Y, Wu T, Weng W, Wan H. Effect of synthesis method the physical and catalytic property of nanosized $\mathrm{NiO}$. Materials Letters. 2007;61:2679-2682.
[24] Li Q, Wang L, Hu B, Yang C, Zhou L, Zhang L. Preparation and characterization of $\mathrm{NiO}$ nanoparticles through calcination of malate gel. Materials Letters. 2007;61:1615-1618.

[25] Thammanoon S, Sumaeth C, Supachai N, Susumu Y. A modified sol-gel process-derived higly nanocrystalline mesoporous $\mathrm{NiO}$ with narrow pore size distribution. Colloid and Surface A: Physicochem Eng Aspects. 2007;296:222-229.

[26] Griffitt BJ, Well R, Hyndman KA, Denslow ND, Powers K, Taylor $\mathrm{D}$, et al. Exposure to copper nanoparticles causes gill injury and acute lethality in zebrafish (Danio rerio). Environ Sci Technol. 2007;41:8178-86.

[27] Wang B, Feng W, Wang T, Jia G, Wang M, Shi J, et al. Acute toxicity of nano-and microscaled zinc powder in healthy adult mice. Toxicol Lett. 2006;161:115-23.

[28] Chen Z, Meng H, Xing G, Chen C, Zhao Y, Jia G, et al. Acute toxicological effects of copper nanoparticles in vivo. Toxicol Lett. 2006;163:109-20.

[29] Meng H, Chen Z, Xing G, Yuan H, Chen C, Zhao F, et al. Ultrahigh reactivity provokes nanotoxicity: explanation of oral toxicity of nano-copper particles. Toxicol Lett. 2007; 175:102-10.

[30] Wang J, Zhou G, Chen C, Yu H, Wang T, Ma Y, et al. Acute toxicity and biodistribution of different sized titanium dioxide particles in mice after oral administration. Toxicol Lett. 2007; 168:176-85.

[31] Kawanishi S, Inoue S, Yamamoto K. Site-specific DNA damage induced by nickel(II) ion and hydrogen peroxide. Carcinogenesis. 1989;10:2231-2235.

[32] Grisham MB, Jourd'heuil D, Wink DA. Chronic inflammation and reactive oxygen and nitrogen metabolism-implications in DNA damage and mutagenesis [Review]. Aliment Pharmacol Ther. 2000;14(suppl 1):3-9.

[33] Ducrocq C, Blanchard B, Pignatelli B, Ohshima H. Peroxynitrite: an endogenous oxidizing and nitrating agent. Cell Mol Life Sci. 1999;55:1068-1077.

[34] Chazotte-Aubert L, Oikawa S, Gilibert I, Bianchini F, Kawanishi S, Ohshima H. Cytotoxicity and site-specific DNA damage induced by nitroxyl anion (NO-) in the presence of hydrogen peroxide. Implications for various pathophysiological conditions. J Biol Chem. 1999;274:20909-20915.

[35] Eiserich JP, Hristova M, Cross CE, Jones AD, Freeman BA, Halliwell B, van der Vliet A. Formation of nitric oxidederived inflammatory oxidants by myeloperoxidase in neutrophils. Nature. 1998;391:393-397.

[36] Clutton S. The importance of oxidative stress in apoptosis. $\mathrm{Br}$ Med Bull. 1997;53:662-668.

[37] Knaapen AM, Borm PJ, Albrecht C, Schins RPL. Inhaled particles and lung cancer. Part A. Mechanisms. Int $J$ Cancer. 2004;109:799-809.

[38] Kang HJ, Sol MY, Park DY, Lee SH, Shin DH, Kim JY, Choi KU, Kim HW, Lee CH, Huh GY. Assessment of Apoptosis by M30 Immunoreactivity and the Relationship with the MSI status and the Clinicopathological Characteristics of Colorectal Carcinomas. Kor J Pathol. 2006;40:319-25.

[39] Leers MP, Kolgen W, Bjorklund V, et al. Immunocytochemical detection and mapping of a cytokeratin 18 neo-epitope exposed during early apoptosis. J Pathol. 199 9;187:567-72.

[40] Caulin C, Salvesen GS, Oshima RG. Caspase cleavage of keratin 18 and reorganization of intermediate filaments during epithelial cell apoptosis. J Cell Biol. 1997;138:1379-94. 